\title{
THE EFFECTS OF BIOLOGICAL CONTROL ON FUNGAL COMMUNITIES COLONIZING EGGPLANT (Solanum melongena L.) ORGANS AND THE SUBSTRATE USED FOR EGGPLANT CULTIVATION
}

\author{
${ }^{1}$ Bożena Cwalina-Ambroziak, ${ }^{2}$ Maciej K. Nowak \\ ${ }^{1}$ Department of Phytopathology and Entomology, University of Warmia and Mazury, \\ 10-720 Olsztyn, Prawocheńskiego 17, Poland \\ e-mail: bambr@uwm.edu.pl \\ ${ }^{2}$ Tymbark SA, Department in Olsztynek, 11-015 Olsztynek, Zielona 16, Poland
}

Received: 18.04.2011

\section{Abstract}

Eggplants, cv. Black Beauty, were grown in the greenhouse of the University of Warmia and Mazury in Olsztyn. During the growing season, the plants were sprayed three times with Asahi SL, Biochikol 020 PC and Bravo 500 SC, they were watered with Polyversum, and a mycorrhizal inoculum was applied to the roots of seedlings. Unprotected plants, treated with distilled water, served as control. After fruit harvest, samples of the substrate used for eggplant cultivation, eggplant stems and roots were collected, and fungi were isolated in the laboratory.

The fungal soil community was more abundant and diverse than the communities colonizing the stems and roots of eggplants. The applied biological and chemical control agents effectively reduced the abundance of fungi, including pathogenic species, in the organs of eggplants and the substrate used for eggplant cultivation. Potential pathogens (Alternaria alternata, Botrytis cinerea and Fusarium species) were isolated in high numbers from eggplant stems in the control treatment and in the Polyversum treatment (67\%). The lowest number of potential pathogenic species were isolated from plants treated with the biostimulator Asahi SL, the fungicide Bravo 500 SC and the mycorrhizal inoculum. The population size of pathogenic fungi (Colletotrichum coccodes and Fusarium) isolated from eggplant roots was smaller, compared with stems, particularly in the treatments with the fungicide Bravo $500 \mathrm{SC}$ and the biostimulator Biochikol $020 \mathrm{PC}$. The soil fungal community was dominated by yeast-like fungi (over $60 \%$ of all isolates). Fungi known as potential causal agents of diseases were found in low abundance, and they were not detected in substrate samples collected from under fungicide-treated eggplant plants.

Key words: eggplant, stems, roots, soil, biological control, pathogenic fungi

\section{INTRODUCTION}

The eggplant (Solanum melongena L.) is grown in many countries of the world due to its high content of bioactive components, including phenolic compounds, macro- and micronutrients (Luthria, 2009). The yield and quality of eggplant fruit are determined, among others, by cultivation form, organic and mineral fertilization, soil moisture content and pathogen infection rates (B lets os et al. 1999; Raig on et al. 2010). During the growing season, eggplant organs are attacked by viruses ( $\mathrm{S} \mathrm{a} \mathrm{d} \mathrm{e} \mathrm{g} \mathrm{h}$ i et al. 2008), bacteria (A rsenijevic et al. 1997; Y e r chy k, 2008), fungus-like organisms such as Phytophthora capsici (S holberg et al. 2007), and soil-borne fungal pathogens including Sclerotinia sclerotiorum, Verticillium spp. and Rhizoctonia solani (L e w is et al. 1998; $\mathrm{J}$ a $\mathrm{n}$ a s et al. 2002). Cases of eggplant infection by the tomato powdery mildew fungus Oidium lycopersi$c i$ have been reported from The Netherlands ( $\mathrm{H} \mathrm{u}$ a $\mathrm{ng}$ et al. 2000).

Developing new cultivars with improved resistance is an important consideration in disease control (P a n the e and Chen, 2010). There has been a growing interest in the use of biological control methods and practices. In a study by $\mathrm{E} 1 \mathrm{~m}$ e r and Fe r r a n d i n o (2009), an increase in the size of snail populations improved the biological state of soil, thus stimulating the growth of eggplant and reducing the symptoms of verticillium wilt. Strains of Bacillus spp., applied to soil or root surface, provided good control of pathogens, such as Verticillium albo-atrum, V. dahliae and $V$. tricorpus ( $\mathrm{T} \mathrm{ja} \mathrm{mos}$ et al. 2004). Biocontrol agents (Polyversum), biotechnological control agents 
(Biosept 33 SL, Biochikol 020 PC) and mycorrhizal inoculum (K a ragi a n nidis et al. 2002) have been increasingly applied in the production of vegetable crops ( $\mathrm{J}$ a $\mathrm{n}$ a s et al. 2002).

The aim of this study was to determine the effects of biological and chemical control agents on the composition of fungal communities colonizing eggplant stems, roots and the substrate used for eggplant cultivation.

\section{MATERIALS AND METHODS}

Eggplants Solanum melongena L., cv. Black Beauty, were grown in the greenhouse of the University of Warmia and Mazury in Olsztyn in 2006-2007. Four-week-old eggplant seedlings were planted in pots filled with peat substrate and garden soil at a ratio of 1:3 (total $9 \mathrm{dm}^{3}$ of the substrate). The experiment involved the following treatments: eggplant sprayed three times with $0.2 \%$ Asahi SL ( $20 \mathrm{ml} / \mathrm{plant})$, plants sprayed three times with $2 \%$ Biochikol (40 ml/plant), plants watered three times with $0.1 \%$ Polyversum $(40 \mathrm{ml} / \mathrm{plant})$, mycorrhizal inoculum (Glomus spp. - Mycoflor ${ }^{\circledR}$ ) applied to the roots of seedlings prior to planting, eggplant sprayed three times with Bravo $500 \mathrm{SC}$ (according to the recommendations of the Institute of Plant Protection-National Research Institute in Poznań). Every treatment comprised six plants (six pots). Pots with unprotected plants served as control. After fruit harvest, samples of substrate from the rhizosphere, stems and roots were collected from each pot. Following disinfection with $50 \%$ ethanol and $1 \%$ sodium hypochlorite, 0.5 $\mathrm{cm}$ pieces of stems and roots were treated with distilled water and placed on PDA medium, in five replications (five Petri dishes x 6 pieces of stems/ roots). After seven days of incubation, fungal colonies were inoculated onto agar slants for later microscopic identification according to standard keys and monographs (A rx, 1970; B o oth, 1971; E1lis, 1971; S kirgiełło et al. 1979; Dom sch et al. 1980; Nels on et al. 1983). Substrate samples collected at a depth of up to $5 \mathrm{~cm}$ under each plant were placed in dishes and mixed with a rotary motion. $1 \mathrm{~g}$ of the resultant fraction was mixed thoroughly with $149 \mathrm{~g}$ fine sand in a flask with a rotary motion for 10 minutes. $300 \mathrm{~mm}^{3}$ of the mixture was poured with Martin medium $\left(50^{\circ} \mathrm{C}\right)(\mathrm{M}$ a ń $\mathrm{k} \mathrm{a}$, 1974). Fungal colonies were transferred on agar slants for later microscopic identification.

\section{RESULTS AND DISCUSSION}

The results of the greenhouse experiment show that fungal communities colonizing the stems and roots of eggplants were characterized by low diversity (Tables 1 and 2). The isolated communities comprised filamentous fungi, yeast-like fungi and non-sporulating fungi. The applied biological and chemical control agents reduced the abundance of fungi, including potential pathogenic species (Alternaria alternata, Botrytis cinerea and five species of the genus Fusarium), compared with the control treatment. Differences in the abundance of these fungi between particular control treatments were significant, except for pathogens isolated from substrate samples (Table 4).

In India, Alternaria tenuissima was found to cause leaf spot and fruit rot on eggplant ( $\mathrm{R} \mathrm{e} \mathrm{d} \mathrm{d} \mathrm{y} \mathrm{and}$ A 11 a m, 2006). W u et al. (2008) detected symptoms of grey mold on eggplant leaves. Fusarium wilt caused by $F$. oxysporum f. sp. melongenae poses a serious problem in many countries (A $1 \mathrm{tin}$ ok and $\mathrm{Can}$, 2010). R o m ber g and D a v is (2007) reported that $F$. solani isolates obtained from tomatoes and potatoes caused root rot in $S$. melongena. In another experiment (P a n t e d i d o s et al. 2009), non-pathogenic strains of $F$. oxysporum colonizing the roots of eggplants lowered the severity of infection caused by $V$. dahliae. In the present study, the above mentioned pathogenic fungi colonized the stems of eggplants from all treatments, except for B. cinerea in plants sprayed with Asahi SL. Pathogens had a high share (over 65\%) of the fungal community colonizing the stems of unprotected plants and plants watered with Polyversum (Fig. 1b). Pathogenic species were isolated in lower numbers $(30 \%$ of all isolates) from eggplant organs in other experimental treatments. The lowest number of Fusarium species were isolated from the stems of plants sprayed with Biochikol 020 PC and Bravo 500 SC. As demonstrated by Hijwegen and Termorshuizen (2000), the synthetic growth inducer Bion (R) had no inhibitory effect on the development of Verticillium wilt caused by the soil-borne pathogen $V$. dahliae in eggplants. In the present experiment, the species Cladosporium cladosporioides and Penicillium had a share of ca. $10 \%$ each in saprotrophic fungi (Fig. 1a). They were isolated from eggplant stems in all treatments. Sporotrichum olivaceum and the species order $M u$ corales (Mucor circinelloides, M. hiemalis, Rhizopus nigricans and Zygorhynchus nigricans) accounted for less than $6 \%$ of all isolates in this fungal community.

Pathogenic fungi were less frequently $(40.6 \%)$ isolated from the roots of eggplants than from the stems (47.6\%) (Fig. 2a). Pathogens were present in the lowest numbers on the roots of plants sprayed with the fungicide Bravo $500 \mathrm{SC}$, and they were represented only by Fusarium species. They colonized the roots of eggplants from all treatments, and were isolated in greatest abundance from plants sprayed with the growth regulator Asahi SL (Fig. 2b). The species Colletotrichum coccodes was present in the largest numbers in control plants. 
Table 1

Fungi isolated from eggplant stems during the investigation period ( $\%$ of isolates)

\begin{tabular}{|c|c|c|c|c|c|c|}
\hline Fungi & $\mathrm{C}^{1}$ & A & B & $\mathrm{P}$ & MI & $\mathrm{Br}$ \\
\hline Alternaria alternata (Fr.) Keissler* & 20.7 & 25.0 & 3.4 & 32.4 & 13.1 & 12.5 \\
\hline Botrytis cinerea Pers* & 20.7 & & 13.8 & 20.7 & 7.9 & 12.5 \\
\hline Chaetomium spirale Zopf & 1.7 & 12.4 & & & 7.9 & \\
\hline Cladosporium cladosporioides (Fres.) de Vries & 13.8 & 18.7 & 3.4 & 8.8 & 10.5 & 5.0 \\
\hline Coniothyrium minitans Campbell & 5.2 & & 3.4 & 8.8 & 5.3 & $5 ., 0$ \\
\hline Epicoccum purpurascens Ehrenb. ex Schlecht & & & 3.4 & & 5.3 & 2.5 \\
\hline Fusarium culmorum (W.G.Sm.) Sacc.* & 3.4 & & 7.0 & & & 2.5 \\
\hline Fusarium equiseti (Corda) Sacc. * & 12.2 & & 13.8 & 11.8 & 5.3 & \\
\hline Fusarium oxysporum Schlecht* & 5.2 & & 3.4 & 2.9 & 5.3 & 5.0 \\
\hline Fusarium poae (Peck.) Wollenweber * & & 6.3 & 7.0 & & & \\
\hline Fusarium semitectum Berk. \& Rav.* & 3.4 & & & & & \\
\hline Gliomastix murorum (Corda) Hughes & 1.7 & 6.3 & & & 5.3 & 5.0 \\
\hline Mucor circinelloides von Tieghem & & 6.3 & & & & \\
\hline Mucor hiemalis Wehmer & 1.7 & & & 5.9 & & \\
\hline Penicillium spp. & 1.7 & 18.7 & 13.8 & 2.9 & 2.6 & 17.5 \\
\hline Rhizopus nigricans Ehrenberg & & & & & 7.9 & 5.0 \\
\hline Sporotrichum olivaceum Fries & 5.2 & 6.3 & 13.8 & 2.9 & & 5.0 \\
\hline Ulocladium botrytis Preuss & & & & & 2.6 & 7.5 \\
\hline Zygorhynchus spp. & & & & & 5.3 & 5.0 \\
\hline Non-sporulating fungi & 3.4 & & 13.8 & 2.9 & 15.7 & 10.0 \\
\hline Total number of isolates & 58 & 32 & 29 & 34 & 38 & 40 \\
\hline
\end{tabular}

${ }^{\mathrm{C}} \mathrm{C}$ - control, A - Asahi, B - Biochikol 020 PC, P - Polyversum, MI - mycorrhizal inoculum, Br - Bravo $500 \mathrm{SC}$, * - pathogenic fungi

Table 2

Fungi isolated from eggplant roots during the investigation period ( $\%$ of isolates)

\begin{tabular}{|c|c|c|c|c|c|c|}
\hline Fungi & $\mathrm{C}$ & A & B & $\mathrm{P}$ & MI & $\mathrm{Br}$ \\
\hline Acremonium strictum $\mathrm{W}$. Gams & & & & & 5.9 & \\
\hline Chaetomium globusom Hughes & & & 12.5 & 2.9 & & \\
\hline Chaetomium pulliliferum Kunze ex Fr. & 2.3 & & & 5.9 & 5.9 & \\
\hline Cladosporium cladosporioides (Fres.) & 4.5 & & & & & 8.3 \\
\hline Colletotrichum coccodes (Wallr.) Hughes* & 29.6 & 15.4 & 17.5 & 17.7 & 23.5 & \\
\hline Coniothyrium minitans Campbell & & 7.7 & & & & 4.2 \\
\hline Fusarium culmorum (W.G.Sm.) Sacc.* & 6.8 & 7.7 & & & & 8.3 \\
\hline Fusarium equiseti (Corda) Sacc.* & 4.5 & 15.4 & & & 8.8 & \\
\hline Fusarium fusarioides (Frag. et Cif.)* & 2.3 & & & & & \\
\hline Fusarium oxysporum Schlecht* & 6.8 & 7.7 & 17.5 & 20.6 & 5.9 & 16.7 \\
\hline Fusarium solani (Mart.) Sacc.* & 2.3 & & & 2.9 & & \\
\hline Gliomastix murorum (Corda) Hughes & & 7.7 & & & & \\
\hline Mortierella alpina Peyronel & 15.9 & & 5.0 & 14.7 & 14.7 & 33.4 \\
\hline Mortierella isabelina Oudemans & 4.5 & 7.7 & & 5.9 & 20.6 & 12.5 \\
\hline Mortierella lignicola(Martin) Gams,Moreau & & & 2.5 & & & \\
\hline Penicillium spp. & & 15.4 & 5.0 & & & \\
\hline Rhizopus nigricans Ehrenberg & & & 12.5 & 2.9 & & \\
\hline Sporotrichum olivaceum Fries & & 15.4 & & 5.9 & & \\
\hline Zygorhynchus spp. & 9.1 & & & & 14.7 & 8.3 \\
\hline Yeast-like fungi & 9.1 & & 25.0 & 14.7 & & \\
\hline Non-sporulating fungi & 2.3 & & 2.5 & 5.9 & & 8.3 \\
\hline Total number of isolates & 44 & 26 & 40 & 34 & 34 & 24 \\
\hline
\end{tabular}

Explanations as in Table 1 
Table 3

Fungi isolated from the substrate used for eggplant cultivation during the investigation period (\% of isolates)

\begin{tabular}{|c|c|c|c|c|c|c|}
\hline Fungi & $\mathrm{C}$ & A & B & $\mathrm{P}$ & MI & $\mathrm{Br}$ \\
\hline Acremonium strictum W. Gams & 0.8 & 0.7 & & 0.5 & & 1.7 \\
\hline Arthrinium sphaeospermum Fuckel & & 0.7 & & & & \\
\hline Aureobasidium pullulans (de Bary) Arnaud & 0.4 & & & & 0.4 & \\
\hline Cladosporium cladosporioides (Fres.) & 0.4 & & 1.1 & 0.9 & 1.1 & 2.2 \\
\hline Colletotrichum coccodes (Wallr.) Hughes * & 0.8 & 0.7 & 1.1 & & & \\
\hline Coniothyrium minitans Campbell & & 0.7 & & & & 0.6 \\
\hline Cordana sp. & & & & & & 0.6 \\
\hline Fusarium avenaceum (Fr.) Sacc.* & 0.4 & & & & & \\
\hline Fusarium culmorum (W.G.Sm.) Sacc. * & & 0.7 & & & 0.4 & \\
\hline Fusarium equiseti (Corda) Sacc .* & & & & & 0.8 & \\
\hline Fusarium fusarioides (Frag. \& Cif.) Booth* & & & & 0.5 & & \\
\hline Fusarium oxysporum Schlecht * & 1.3 & & & & 0.4 & \\
\hline Gilmaniella humicola Barron & & & & & 0.4 & 0.6 \\
\hline Gliomastix murorum (Corda) Hughes & & 2.2 & 0.4 & 0.9 & 2.3 & 2.2 \\
\hline Mortierella alpina Peyronel & 0.8 & & & & & 2.2 \\
\hline Mortierella isabelina Oudemans & 0.4 & & & 2.3 & & 1.1 \\
\hline Mucor hiemalis Wehmer & 1.3 & 3.5 & 2.9 & 0.5 & 1.1 & \\
\hline Paecilomyces niveus Stolk et Samson ** & 9.2 & & & 8.0 & 2.7 & 9.6 \\
\hline Paecilomyces lilacinus (Thom) Samson ** & 10.2 & 2.8 & 17.3 & 9.8 & 10.7 & 2.8 \\
\hline Paecilomyces variotti Bainier** & & 0.8 & & 3.6 & 7.2 & \\
\hline Papulaspora irregularis Hotson & & 2.2 & & & & \\
\hline Penicillium spp. & 1.7 & 4.9 & 6.1 & 3.6 & 2.1 & 5.1 \\
\hline Rhizopus nigricans Ehrenberg & & & 2.2 & & & \\
\hline Sporotrichum carnis Books and Hansford & 0.4 & & & 1.4 & 4.2 & \\
\hline Sporotrichum olivaceum Fries. & 10.8 & 0.7 & 7.9 & 5.0 & 1.1 & 10.7 \\
\hline Trichoderma aureoviride Rafii** & & & 0.4 & 0.5 & 0.4 & 0.6 \\
\hline Trichoderma hamatum (Bon) Bain ** & & & 1.1 & & 0.8 & 0.6 \\
\hline Trichoderma harzianum Rifai** & 0.8 & 2.8 & 1.1 & & & \\
\hline Trichoderma koningii Oudemans $* *$ & & & 1.8 & & 2.7 & \\
\hline Trichoderma polysporum (Link ex Pers.) Rifai** & & & 0.4 & & & \\
\hline Yeast-like fungi & 60.3 & 76.6 & 56.2 & 62.5 & 61.2 & 59.4 \\
\hline Total number of isolates & 240 & 282 & 278 & 222 & 263 & 178 \\
\hline
\end{tabular}

Explanations as in Table 1

Table 4

Fungi isolated most frequently from eggplant organs and substrate (mean number of isolates in years)

\begin{tabular}{|c|c|c|c|c|c|c|c|c|c|c|c|c|}
\hline \multirow{2}{*}{ Treatments } & \multicolumn{4}{|c|}{ Stems } & \multicolumn{3}{|c|}{ Roots } & \multicolumn{5}{|c|}{ Substrate } \\
\hline & Path & Cl.cl & Muc & Pen & Path & Muc & Yeast & Path & Antag & Muc & Yeast & Pen \\
\hline Control & $19.0 \mathrm{a}^{* *}$ & $4.0 \mathrm{a}$ & $0.5 \mathrm{a}$ & $0.5 \mathrm{a}$ & $11.5 \mathrm{a}$ & $6.5 \mathrm{ab}$ & $2.0 \mathrm{a}$ & $3.0 \mathrm{a}$ & $25.0 \mathrm{a}$ & $1.5 \mathrm{a}$ & $73.0 \mathrm{a}$ & $2.0 \mathrm{a}$ \\
\hline Asahi SL & $5.0 \mathrm{~b}$ & $3.0 \mathrm{a}$ & $1.0 \mathrm{a}$ & $3.0 \mathrm{a}$ & $6.0 \mathrm{~b}$ & $2.0 \mathrm{~b}$ & $1.0 \mathrm{a}$ & $2.0 \mathrm{a}$ & $9.0 \mathrm{a}$ & $5.0 \mathrm{a}$ & $108.0 \mathrm{a}$ & $7.0 \mathrm{a}$ \\
\hline Biochikol 020PC & $7.0 \mathrm{~b}$ & $1.0 \mathrm{a}$ & $0 \mathrm{a}$ & $2 ., 0 \mathrm{a}$ & 7.0ab & $4.0 \mathrm{ab}$ & $5.0 \mathrm{a}$ & $1.5 \mathrm{a}$ & $30.5 \mathrm{a}$ & $8.0 \mathrm{a}$ & $78.0 \mathrm{a}$ & $8.5 \mathrm{a}$ \\
\hline Polyversum & $11.5 \mathrm{ab}$ & $1.5 \mathrm{a}$ & $1.0 \mathrm{a}$ & $0.5 \mathrm{a}$ & $7.0 \mathrm{ab}$ & $4.0 \mathrm{ab}$ & $2 ., 5 \mathrm{a}$ & $0.5 \mathrm{a}$ & $24.5 \mathrm{a}$ & $3.0 \mathrm{a}$ & $69.5 \mathrm{a}$ & $4.0 \mathrm{a}$ \\
\hline $\mathrm{MI}^{*}$ & $5.0 \mathrm{~b}$ & $2 ., 0 \mathrm{a}$ & $2.5 \mathrm{a}$ & $0 \mathrm{a}$ & $6.5 \mathrm{ab}$ & $8.5 \mathrm{ab}$ & $0 \mathrm{a}$ & $2.0 \mathrm{a}$ & $32.0 \mathrm{a}$ & $1.5 \mathrm{a}$ & $80.5 \mathrm{a}$ & $3.0 \mathrm{a}$ \\
\hline Bravo $500 \mathrm{SC}$ & $6.5 \mathrm{~b}$ & $1.0 \mathrm{a}$ & $2.0 \mathrm{a}$ & $3.5 \mathrm{a}$ & $6.0 \mathrm{~b}$ & $6.5 \mathrm{ab}$ & $0 \mathrm{a}$ & $0 \mathrm{a}$ & $12,0 \mathrm{a}$ & $3.0 \mathrm{a}$ & $53.0 \mathrm{a}$ & $4.5 \mathrm{a}$ \\
\hline
\end{tabular}

Explanations: Path - pathogens, Cl.cl - Cladosporium cladosporioides, Muc - Mucorales, Pen - Penicillium spp. Yeast - yeastlike fungi, Antag - antagonists

*MI - mycorrhizal inoculum, ** means with the same letter do not differ significantly (Duncan's test, $\mathrm{p}=0.01$ ) 
$\%$

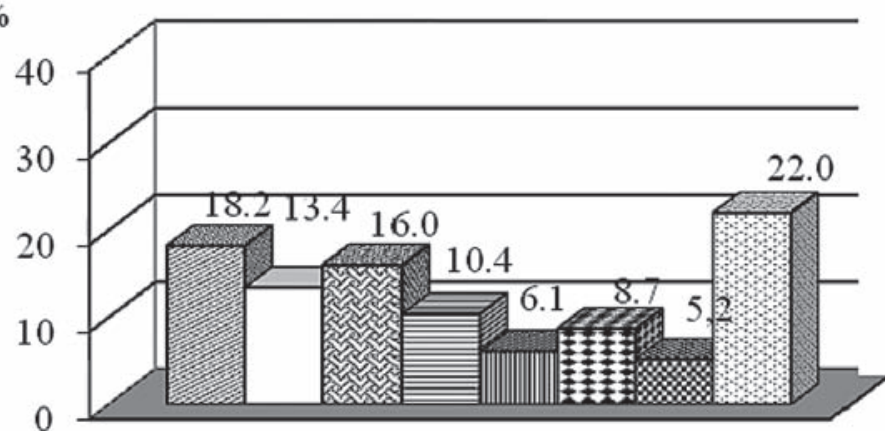

\section{\$Aiternaria alternata}

$\square$ Botrytis cinerea

圈 Fusarium spp.

日Cladosporium cladosporioides

四ucorales

Genicillium sp $\mathrm{sp}$

Sporotrichum olivaceum

口others

a. major groups of fungi

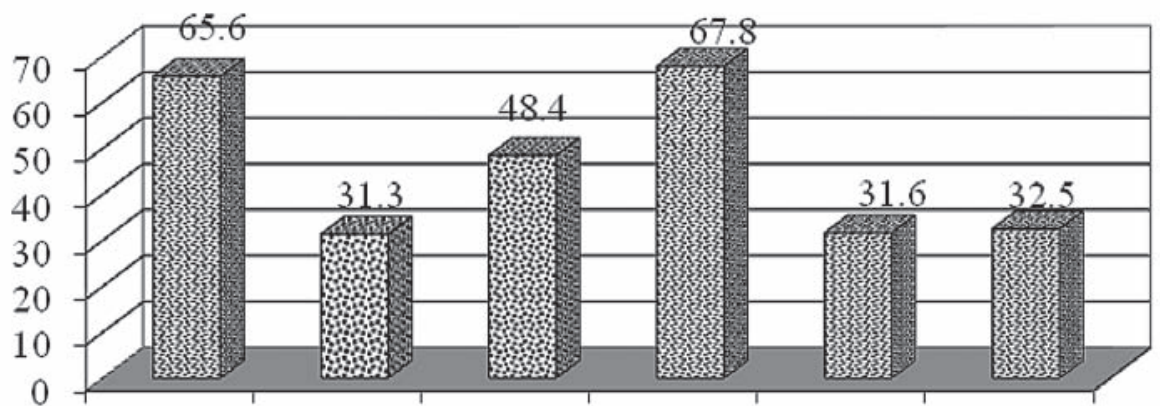

control Asahi SL Biochikol P(Polyversummycorrhizal Bravo 500 S.C.

b. pathogens

Fig. 1. Fungal species groups isolated from eggplant stems

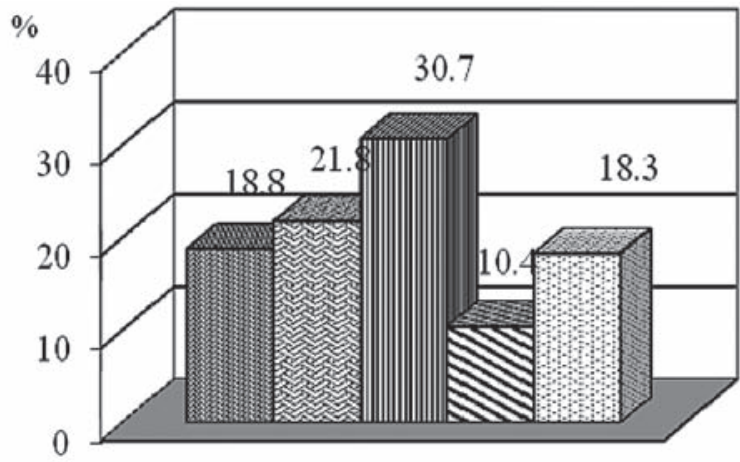

- Colletotrichum coccodes

图 Fusarium spp.

四Mcorales

口yeast-likefungi

囚others

a. major groups of the fungi

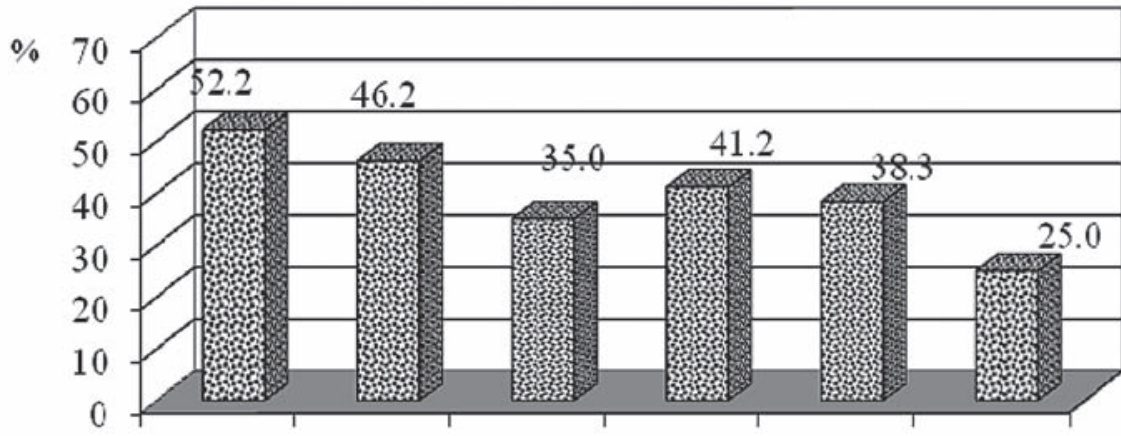

control Asahi SL Biochikol PolyversummycorhizaBravo 500SC 020 PC

b. pathogens

Fig. 2. Fungal species groups isolated from eggplant roots 


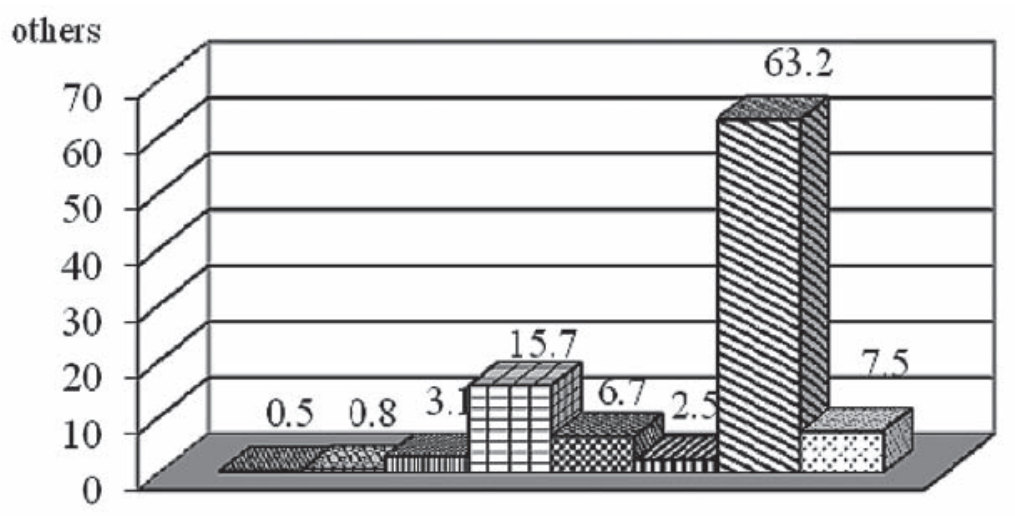

Colletotrichum coccodes

Fusarium spp.

mincorales

$\square$ Paecilomyce spp.

Sporotrichum oivaceum

m Trichoderma spp.

EYeast-like fungi

⿴囗十 others

a. major groups of fungi



Fig. 3. Fungal species groups isolated from substrate

According to J anas et al. (2002), Biosept 33 SL, Polyversum and Amistar 250 SC offer effective control of soil pathogens, in particular $S$. sclerotiorum and $V$. dahliae, and they also stimulate the growth of eggplants and improve the yield. Fre e m a n (2008) reported that $C$. acutatum may asymptomatically colonize eggplants, tomatoes and peppers. In the present study, saprotrophic fungi of the order Mucorales accounted for over $30 \%$ of all isolates, and the dominant species were Mortierella alpina and M. isabelina. Yeast-like fungi had a three-fold lower share of the community. They developed primarily on the roots of plants treated with Polyversum and Biochikol 020 PC.

The soil fungal community was most diverse, and it consisted of as many as 30 species (Table 3). Yeast-like fungi occurred in greatest abundance over $60 \%$ of all isolates (Fig. 3a). Pathogenic fungi were seldom isolated from the substrate, and they accounted for only $2.5 \%$ of all isolates in the control treatment (Fig. 3b). Pathogenic species were much more frequently found on the roots and stems of eggplants, and they were not present in substrate samples collected from under fungicide-treated plants. Fungi showing antagonistic activity against pathogens were more commonly isolated (18.2\% of all isolates, five Paecilomyces species and five Trichoderma species). $\mathrm{N}$ a g t z a a m et al. (1998) reported that a combination of Gliocladium roseum and Talaromyces flavus incorporated in soil reduced colonization of roots and infection of eggplants by $V$. dahliae. In a study by $\mathrm{L}$ e w is et al. (1998), T. hamatum and G. virens applied to soil reduced damping-off of eggplant seedlings caused by Rhizoctonia solani. W u et al. (2008) described hyperparasitic potential of $T$. harzianum over S. sclerotiorum, a dangerous pathogen of eggplant seedlings, which was manifested as inhibition of mycelial growth and sclerotia production. The above mentioned antagonistic fungi colonized the substrate from all treatments, and the applied mycorrhizal inoculum supported their growth. K a r a g i a n $\mathrm{nid}$ is et al. (2002) observed a beneficial influence of the arbuscular mycorrhizal fungus (AMF) Glomus mosseae which increased the macronutrient and micronutrient uptake by plants and reduced $V$. dahliae infection rates. 


\section{CONCLUSIONS}

Potential pathogenic fungi (A. alternata, B. $\mathrm{ci}$ nerea, $C$. coccodes and Fusarium species) more frequently colonized the stems and roots of Solanum melongena in particular treatments with biological and chemical control than the substrate used for eggplant cultivation.

The applied biological and chemical control agents effectively reduced the populations of pathogenic fungi colonizing eggplant stems, compared with the control treatment.

The lowest number of potential pathogenic species were isolated from the stems of eggplants treated with the biostimulator Asahi SL and the fungicide Bravo $500 \mathrm{SC}$, and from the roots of fungicide-treated plants.

The fungal community isolated from the substrate used for eggplant cultivation was dominated by yeast-like fungi.

\section{REFERENCES}

Altinok H.H., Can C., 2010. Characterization of Fusarium oxysporum $\mathrm{f}$. sp. melongenae isolates from eggplant in Turkey by pathogenicity, VCG and RAPD analysis. Phytoparasitica, 38 (2): 149-157.

Arsenijević M., Trkulja V., Obrdović A., 1997. Pathogenic and bacteriological characteristics of Yugoslav Erwinia soft rot strains originating from pepper and eggplant fruits. Zeitsch. Pflanzenkrank. Pflanzensch. 104 (4): 394-402.

Arx von J. A., 1970. The genera of fungi sporulating in pure culture. Verlag von J. Cramer.

Bletsos F.A., Thanassoulopoulos C.C., Roupa ki a s D.G., 1999. Water stress and verticillium wilt severity on eggplant (Solanum melongena L.). J. Phytopathol. 147 (4): 243-248.

B ooth T.C., 1971. The genus Fusarium. Commonwealth Mycological Institute Kew Surrey, England.

Domsch K.H., Gams W., Anderson TrauteHeidi, 1980. Compendium of Soil Fungi. Academic Press, A Subsidiary of Harcourt Brace Jovanovich Publishers, London, New York, Toronto, Sydney, San Francisco: 859.

E11 is M.B., 1971. Dematiaceus hyphomycetes. Commonwealth Mycological Institute Kew Surrey, England.

E1mer W.H., Ferrandino F.J., 2009. Suppression of Verticillium wilt of eggplant by earthworms. Plant Dis. 93 (5): 485-489.

Freeman S., 2008. Management, survival strategies, and host range of Colletotrichum acutatum on strawberry. Hort Sci. 43 (1): 66-68.

Hijwegen T., Termorshuizen A.J., 2000. Retarded development of Verticillium wilt in eggplant after ap- plication of Bion (R) or Oryzalin (R). Zeitsch. Pflanzenkrank. Pflanzensch. 107 (3): 267-273.

Huang C.C., Biesheuvel J., Lindhout P., Niks R.E., 2000. Host range of Oidium lycopersici occurring in the Netherlands. Europ. J. Plant Pathol. 106 (5): 465-473.

Janas R., Szafirowska A., Kołosowski S., 2002. Zastosowanie biopreparatów w biologicznej ochronie oberżyny. / The application of bioagents in biological control of eggplant. Prog. Plant Protection/Post. Ochr. Roślin, 42 (2): 417-419. (in Polish).

Karagiannidis N., Bletsos F., Stavropoulos N., 2002. Effect of Verticillium wilt (Verticillium dahliae Kleb.) and mycorrhiza (Glomus mosseae) on root colonization, growth and nutrient uptake in tomato and eggplant seedlings. Sci. Horticult. 94 (1-2): 145-156.

Lewis J.A., Larkin R.P., Rogers D.L., 1998. A formulation of Trichoderma and Gliocladium to reduce damping-off caused by Rhizoctonia solani and saprophytic growth of the pathogen in soiless mix. Plant Dis. 82 (5): 501-506.

Luthria D.L., 2009. Phenolic compounds analysis in foods and dietary supplements is not the same using different sample preparation procedures. Acta Horticulturae, 841: 381-387.

Mańka K., 1974. Zbiorowiska grzybów jako kryterium oceny wpływu środowiska na choroby roślin. / Fungal communities as a criterion for estimating the effect of the environment on plant diseases. Zesz. Probl. Post. Nauk Rol. 160: 9-23. (in Polish)

Nagtzaam M.P. M., Bollen G.J., Termorshuizen A.J., 1998. Efficacy of Talaromyces flavus alone or in combination with other antagonists in controlling Verticillium dahliae in growth chamber experiments. J. Phytopathol. 146 (4): 165-173.

Nelson P.E., Toussoun T.A., Marasas W.F.O., 1983. Fusarium species. The Pensylvania State University Press, University Park and London.

Pantelides L.S., Tjamos S.E., Striglis L.A., Chatzipavlidis L., Paplomatas E.J., 2009. Mode of action of a nonpathogenic Fusarium oxysporum strain against Verticillium dahliae using Real Time QPCR analysis and biomarker transformation. Biol. Control, 50 (1): 30-36.

Panthee D.R., Chen F., 2010. Genomics of fungal disease resistance in tomato. Current Genomics, 11 (1): 30-39.

Raigon M.D., Rodríguez-Burruezo A., Prohens J., 2010. Effects of organic and conventional cultivation methods on composition of eggplant fruits. J. Agric. Food Chem. 58 (11): 6833-6840.

Reddy A.V.R., A11am U.S., 2006. First report of Alternaria tenuissima causing leaf spot and fruit rot on eggplant (Solanum melongena) in India. Plant Pathol. 55 (4): 579.

Romberg M.L., Davis R.M., 2007. Host range and phylogeny of Fusarium solani f. sp. eumartii from 
potato and tomato in California. Plant Dis. 91 (5): $585-$ 592.

Sadeghi M.S., Behjatnia S.A.A., Masumi M., Izadpanah K., 2008. Characterisation of a strain of potato virus $\mathrm{Y}$ causing eggplant mosaic in southern Iran. Austral. Plant Pathol. 37 (1): 79-86.

Sholberg P.L., Walker M.C., O'Gorman D.T., Jesperson G.D., 2007. First report of Phytophthora capsici on cucurbitas and peppers in British Columbia. Can. J. Plant Pathol. 29 (2): 153-158.

Skirgiełło A., Zadara M., Ławrynowicz M., 1979. Grzyby (Mycota). 10. Glonowce (Phycomycetes). Pleśniakowe (Mucorales). PAN Instytut Botaniki, Warszawa-Kraków. (in Polish).

Tjamos E.C., Tsitsigiannis D.I., Tjamos S.E., Antoniou P. P., Katinakis P., 2004. Selection and screening of endorhizosphere bacteria from solarized soils solanaceous hosts. Eur. J. Plant Pathol. 110 (1): $35-44$.

Wu D., Feng L., Zhang C., He Y., 2008. Early detection of Botrytis cinerea on eggplant leaves based on visible and near-infrared spectroscopy. Transactions of the American Society of Agricultural and Biological Engineers, 51 (3): 1133-1139.

Yerchyk V., 2008. Virulence of strains of Clavibacter michiganensis subsp. sepedonicus. Zemdirbyste, 95 (3): 359-365.

\section{Wpływ ochrony biologicznej na zbiorowisko grzybów zasiedlających łodygi i korzenie oraz podłoże spod uprawy oberżyny (Solanum melongena L.)}

\section{Streszczenie}

Oberżynę odmiany Black Beaty uprawiano w latach 2006-2007 w szklarni Uniwersytetu Warmińsko-Mazurskiego w Olsztynie. W okresie wegetacji zastosowano ochronę w postaci 3-krotnego opryskiwania roślin preparatami: Asahi SL, Biochikol 020 PC, Bravo 500 SC i podlewania roślin Polyversum oraz aplikacji szczepionki mikoryzowej pod korzenie rozsady. Kombinację kontrolną stanowiły rośliny bez ochrony, traktowane wodą destylowaną. Po zbiorach owoców pobierano materiał roślinny (łodygi i korzenie) oraz podłoże spod uprawy oberżyny w celu izolacji grzybów.

Zbiorowisko grzybów glebowych było bardziej liczne i zróżnicowane niż zbiorowisko grzybów zasiedlających łodygi i korzenie oberżyny. Zastosowana ochrona ograniczała liczebność patogenów $\mathrm{w}$ analizowanych częściach roślin i w podłożu. Potencjalne patogeny (A. alternata, B. cinerea i Fusarium spp.) licznie zasiedlały łodygi oberżyny w kombinacji kontrolnej i z opryskiwaniem Polyversum (67\%). Najmniej potencjalnych patogenów wyizolowano z roślin w kombinacji z użytym stymulatorem wzrostu Asahi SL i fungicydem Bravo 500 SC oraz ze szczepionką mikoryzową. Z korzeni uzyskano mniejszą populację patogenów (C. coccodes i Fusarium spp.) niż z łodyg, zwłaszcza z roślin opryskiwanych fungicydem i stymulatorem odporności Biochikol 020 PC. W glebie dominowały grzyby drożdżopodobne - ponad $60 \%$ izolatów. Potencjalni sprawcy chorób nielicznie zasiedlali podłoże spod uprawy oberżyny, a nie było ich w ogóle w uprawie roślin chronionych chemicznie. 